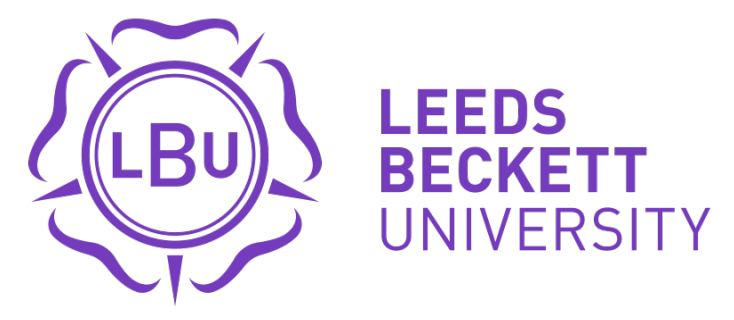

Citation:

Spracklen, K (2016) Bravehearts and Bonny Mountainsides: Nation and History in Scottish Folk/Black Metal. Rock Music Studies. ISSN 1940-1159 DOI: https://doi.org/10.1080/19401159.2016.1253297

Link to Leeds Beckett Repository record:

https://eprints.leedsbeckett.ac.uk/id/eprint/3146/

Document Version:

Article (Accepted Version)

The aim of the Leeds Beckett Repository is to provide open access to our research, as required by funder policies and permitted by publishers and copyright law.

The Leeds Beckett repository holds a wide range of publications, each of which has been checked for copyright and the relevant embargo period has been applied by the Research Services team.

We operate on a standard take-down policy. If you are the author or publisher of an output and you would like it removed from the repository, please contact us and we will investigate on a case-by-case basis.

Each thesis in the repository has been cleared where necessary by the author for third party copyright. If you would like a thesis to be removed from the repository or believe there is an issue with copyright, please contact us on openaccess@leedsbeckett.ac.uk and we will investigate on a case-by-case basis. 


\title{
Bravehearts and Bonny Mountainsides: Nation and History in Scottish Folk/Black
}

\section{Metal}

\begin{abstract}
Music, art, culture and leisure are elements or tools of political nationalism, of hegemonic control and of counter-hegemonic resistance. In the Scottish independence referendum, pop and rock musicians came out on either side, lending their voice, their celebrity and their music to save the United Kingdom or to support a new nation. In this paper, Scottish nationalism and Scottish identity is explored through two folk/black metal bands that have emerged on the extreme metal scene from Scotland: Saor and Cnoc An Tursa. I use an online semiotic analysis over a three-year period including the period of the referendum, along with an analysis of their lyrics and imagery, to show how each band has used Scottishness and responded to Scottish nationalism - and how fans have constructed Scottishness in their critical appreciation of the band's songs and other identity-work. I argue that some progressive ideology exists, but it is situated within wider ideologies in metal, and wider assumptions about Scotland.
\end{abstract}

Key words: folk/black metal, Scotland, Scottishness, Celticness, nationalism, authenticity 


\section{Introduction}

In the creative hands and minds of its rock musicians, Scotland dreams. In the minds of its music's fans, Scotland awakes. In the popular imagination of the global North, Scotland is an empty land of mountains, highland streams, heather and men in kilts: the Scotland invented in the nineteenth-century by British elites (see Hesse; Spracklen, "Dreaming of Drams"). Tourists visit Scotland because they have seen the film Braveheart, or they have tasted a single-malt whisky from Speyside or Islay, and they want to find the authentic land from which this spirit comes. The supposed reality of Scotland is constructed for these visitors and outsiders by their choices in consumption, music, culture and art, choices that they make because they help them construct this world of "bonny mountainsides": the sound of bagpipes; the poetry of Burns; and even the accents of Scottish folk-rock singers. This construction of Scotland and Scottishness is taking place alongside a growing political movement for Scottish devolution, autonomy and full independence. Modern Scottish nationalism, then, is inevitably shaped and viewed through such ersatz Scottishness, and is subject to its own imagining. The Scottish independence movement has grown exponentially in the first few years of this century. The Scottish Nationalist party (SNP) has won election after election, becoming the party of government in Scotland in 2011 and winning over fifty seats in Scotland in the 2015 United Kingdom $^{1}$ (UK) General Election. Despite the vote against independence in the referendum of September 2014, the nationalists have increased their popularity in opinion polls, and there is a public sphere where an independent Scotland is accepted and celebrated as an eventuality in the near future. Scotland's nationalists have not only rejected English and British nationalism, but they have claimed to represent a

\footnotetext{
${ }^{1}$ Scotland and England are separate countries in the United Kingdom of Great Britain and Northern Ireland. There is a Scottish Parliament, and a British Parliament for the United Kingdom that includes Scottish members, but no English Parliament.
} 
progressive, left-wing politics that champions the welfare state, education, multiculturalism and the working classes against the inequities of neo-liberalism (Mycock; Paterson).

Music, art, culture and leisure are elements or tools of political nationalism, of hegemonic control and of counter-hegemonic resistance. In the Scottish independence referendum, pop and rock musicians came out on either side, lending their voice, their celebrity and their music to save the United Kingdom or to support a new nation (Gardiner). In heavy metal, and the scenes of the extreme sub-genres of folk metal, heathen metal and black metal, regionalism and nationalism has been justified (by some in those scenes) as part of an ideology of elitism, and of exclusive authenticity (see discussions in Hoad; Weston; Spracklen, Lucas and Deeks). In this form, extreme metal (here folk/black metal) becomes a potential space for the reproduction of elitist ideologies and normative gender politics. Bands and fans have embraced or at least performed the politics of hegemonic, white masculinity at the heart of this appropriation or mythologizing of identity and history (Lucas, Deeks and Spracklen; Spracklen, Lucas and Deeks; Spracklen, "To Holmgard... and Beyond”). While this mythologizing operates to perpetuate hegemonies where they exist, there is the possibility that extreme metal might actually be used to challenge dominant ideologies. In this paper, Scottish nationalism and Scottish identity is explored through two extreme metal bands that have emerged on the folk/black metal scene from Scotland: Saor and Cnoc An Tursa. I use a semiotic analysis of their Facebook pages and other internet sites reporting on the two bands over a three-year period including the period of the referendum, along with an analysis of their lyrics and imagery, to show how each band has used Scottishness and responded to Scottish nationalism - and how fans have constructed Scottishness in their critical appreciation of the band's songs and other identity-work. I will show how some progressive ideology exists, but it is situated within wider ideologies in metal, and wider assumptions about Scotland. 
In the next section of the paper, I discuss the key historical and political context of Scotland and its independence movement, for those unfamiliar with the circumstances of modern Scottish nationalism. After the context section I develop a theoretical framework based on three related concepts: Hobsbawmian invented traditions of Celticness; hyperreality, distilled through the work of Baudrillard and Eco; and the tension between communicative rationality and instrumentality at the heart of modern nation-state building identified in the work of Jürgen Habermas. I will then proceed to describe my methodological choices, before introducing the bands of the case study and my broader discussion and analysis of them and their fans.

\section{Scotland and Scottish Independence}

On 18 September 2014 the voters of Scotland, the northern-most country in the modern nation known as the United Kingdom, were offered the opportunity to vote for ("yes") or against ("no") full independence from the other parts of the UK: essentially, independence from England and London. The campaign for the referendum vote had been led by the SNP, who had taken full control of the Scottish parliament in 2011 after being elected on a policy platform that included a referendum. On the morning of 19 September 2014 it was announced that:

Scotland has voted to stay in the United Kingdom after voters decisively rejected independence. With the results in from all 32 council areas, the "No" side won with 2,001,926 votes over 1,617,989 for "Yes". Scotland's First Minister Alex Salmond called for unity and urged the unionist parties to deliver on more powers. Prime Minister David Cameron said he was delighted the UK would remain together and that commitments on extra powers would be honoured "in full". Mr Cameron said the 
three main unionist parties at Westminster would now follow through with their pledge of more powers for the Scottish Parliament. (BBC)

The SNP had been campaigning for full Scottish independence since its formation in the early twentieth-century, and its founders were inspired by the popular and populist nationalism of the period: they embraced the idea of Scotland as nation betrayed and captured by the English, and dreamed of Scotland being for the Scottish, flirting with notions of racial purity (Gardiner; Mycock). Scotland had been an independent state for hundreds of years in the Middle Ages, and had roots in earlier kingdoms, though it arguably shared a common history and elite Norman culture with England (Gardiner). At times in the early Middle Ages political hegemonies (most importantly the Picts and the Irish "Scots") in what is now Scotland were united by a shared Celtic language, and such hegemonies controlled parts of what is now England (Davies). The emergence of Alba as kingdom in the north of the British Isles came about by a merger of various smaller states. By the seventeenth-century, Alba was called Scotland by the English and by the English-speaking elites of southern Alba, and the King of Scotland was close enough to the English elites to be invited to take the crown of England after the death of Elizabeth the First. Scotland became closer to England, despite various wars and uprisings, and by the start of the eighteenth-century the Act of Union brought both nations together into Great Britain, and the Scottish parliament was dissolved to merge in with that of England. In the next two hundred years, once the final rebellions had been put down, Scotland continued to have its own legal system, but was ruled directly from London. Scotland's central belt, including Glasgow, was a part of the industrial heartlands that nurtured the rise of the British Empire. At the height of British imperialism, elites from the south of England bought-up large areas of land in the Highlands and Islands of Scotland, established hunting estates and invented quaint Scottish traditions. 
In the last decades of the twentieth century, the right-wing romantic nationalism of the SNP's early supporters was displaced by a more progressive, civic nationalism that embraced diversity, but which still argued that Scotland would be a better place it if rejected the political control from London and England (Gardiner; Mycock; Paterson). This new form of Scottish nationalism identified the Conservative party and their support of neo-liberalism as the cause of Scotland's socio-economic problems: the Conservative policies had deliberately wracked the industrial base of working-class communities across the United Kingdom, but in Scotland this was - and is perceived as an arrogance of English imperialism, which devalues and limits the right of Scotland to maintain its own affairs (Gardiner; Spracklen, "Bottling Scotland"). Measures to give Scotland autonomy and devolved power, especially the creation of the Scottish parliament, have only served to give the SNP more political support. And although the referendum was lost, enough people voted yes for the independence movement to swing votes massively towards the SNP in the 2015 UK General Election. There are now thousands of active campaigners fighting for social justice and progressive politics in Scotland, aligned with the SNP and the wider independence movement (Gardiner 1).

\section{Theoretical Framework}

Invented Traditions, Imagined and Imaginary Communities: Music, Culture and Celticness Scottishness and the related form of identity called Celticness (see Hesse; Kader; Matheson; McArthur; Spracklen, "Dreaming of Drams"; Wood) are both constructed in the sharing and negotiating of invented traditions. In their seminal edited collection on the idea of the invented tradition, Hobsbawm and Ranger show how all historical and cultural traditions are essentially invented by the people who have the power to do so. That is not to say that such invented traditions are altogether empty of significance (for example, it is a historical fact that many people in Scotland before the modern era spoke Scottish Gaelic, and some 
continue to speak the language today), but their status as essential parts of a nation's historical identity is assured by the invention of the modern nation-state and romantic, conservative nationalism (Spracklen, Lucas and Deeks 60-62). Music is one form of culture in which such identities are fixed by invented traditions (see Baxter-Moore; Bohlman; dell'Agnese; Fossum; Matheson). Benedict Anderson's book Imagined Communities describes how new nations use folk music and popular music as ways to construct a fictive ethnicity. The imagined community might be understood as a form of nationalism constructed from invented traditions and justified by historical myth-making. It is related to what anthropologists such as Cohen argues is symbolic community, a form of belonging and exclusion that uses invented traditions and cultural forms alongside negotiations of power and status and meaning in the present day. This symbolic community is the imaginary community identified in the work of Spracklen, Lucas and Deeks (61) on Englishness in extreme metal.

The social construction of Scottishness and Scottish imaginary community has been the subject of a huge number of critical accounts (Hesse; McArthur). Scottish drinks and food have been identified as being constructed as essential Scottish products: my own research on Scottish whisky, for example, shows how whisky fans and whisky producers align their own invented traditions with one another (see Spracklen, "Dreaming of Drams"; Spracklen, "Bottling Scotland"). Scottish tartans and clans have been idealized across the world by people who want to dress and act as highlanders (Hesse 1-2). This is related to the search for some supposedly authentic Celtic identity, which has seen the reification of Irish invented traditions, the adoption of Irishness by millions of people who are not Irish and the growth of an interest in Irish music and Celtic music festivals (Fossum; Matheson). Scottish music in its various forms has been identified as constructing Scottishness, whether a romantic Scotland of bagpipes and heather-covered mountains, or the urban Scotland of the Central Belt (Wood). That there is nothing essential about Scotland and Scottish identity, or Celticness 
and Celtic identity, is a truth that is clear enough - but this idealized, Celtic version of Scotland and Scottishness retains its hold around the world, even as Scotland's liquid and polysemic present is very different to this imagined and fixed past (see Gibson; Hesse; McArthur).

\section{Hyper-reality and Authenticity}

Baudrillard remains the key theorist who has discussed hyper-reality and authenticity. For Baudrillard, everything cultural is a simulation constructed in this particular stage of modernity - and that simulation constructs a form of reality he calls hyper-reality. In his famous account of the mediation of the first Gulf War, Baudrillard does not suggest that the war does not take place - but it may as well have not taken place, given our consumption of the mediated war reports. Baudrillard says true knowledge about the state of the world, and true knowledge about what actually happens - our epistemological and ontological lens in the global North - is always mediated by popular culture. In music, then, we might use Baudrillard's version of hyper-reality to show how authenticity, belonging and nation are all subject to such mediation (see Bratus; P. Brown). That is, the individual's search for authenticity and the claims made about the authentic are searches and claims mediated (constructed and constrained) through global capitalism and hegemony.

In the book Foucault's Pendulum, Umberto Eco describes how some editors at a small Italian publishing house begin to concoct a fabulous story about how a gnostic tradition has been preserved through history. They know the story is nonsense, and they revel in making unjustified connections and leaps in logic, ignoring counter-evidence to their narrative, or making up evidence to support it. This is Eco's reflection on the alternative history and myth-making that has its own best-selling books, the non-fiction The Holy Blood and the Holy Grail (Baigent, Leigh and Lincoln), and (more recently) the fiction of Dan 
Brown's The Da Vinci Code. At first the publishers, like Eco, consider it all a big joke. But the more they make up the invented tradition, the more they make it more incredible, the more people want to believe it, and the more it becomes a truth for those who end up murdering for it. What Eco's fiction shows reflects Eco's academic interest in hyper-reality and authenticity outlined in Faith in Fakes. Hyper-reality, for Eco, is what happens when our pre-modern modes of thinking combine with and are changed by the rise of modernity and the spread of a global, secular, popular culture. Hyper-reality, the mediated reality of the television screen and the comic strip, is the only way we feel belonging and emotion, the sense of the numinous and the sacred. In this world of disenchantment we find solace, meaning and belonging in fakes and the inauthentic. But crucially, for this paper and for our understanding of hyper-reality and myths, Eco argues that it is our "political duty" ("Faith in Fakes" ix) to explore how stories about the past and the present are shaped by those with power. The hyper-real for Eco does not lead to a lack of signification and cultural relativism: it is still grounded in things that happened, and in the struggle over the meaning of signs who gets to define the past and culture is crucial.

\section{Nations, Nationalism and Instrumentality}

Although there are states that have pre-modern roots and continuities, nation-states are a product of modernity - the period of time beginning in the Enlightenment in the global North, and moving through industrialization, urbanization, capitalism and imperialism (see Anderson; Davies; Hobsbawm and Ranger). Modern nation-states need to recruit citizens into armies, factories and other work places as willing agents in their own constraint, so nationalist ideology in the nation-building phase of high modernity worked in a hegemonic fashion (Gramsci).That is, such nationalism played on deep feelings of belonging, creating symbolic boundaries between the nation-state and its external rivals, while creating the false 
narrative of equality and liberty within the nation-state's class structures. This form of nationalism, which might be called romantic or conservative, was often predicated on the myth of racial purity, or religious purity, or the idea that a particular people had a right to a particular space, or more often a combination of all three (Anderson; Gardiner). This is the nationalism of patriots, racists and hegemonic elites. Against this romantic nationalism can be placed what might be called civic nationalism, where belonging is open to everyone who lives in the nation-state, and where the rights of individual citizens (and migrants who might desire to become citizens) are described and protected by constitutions (Mouritsen and Olsen). Whether civic nationalism can actually be an ideology of inclusion while being an ideology of exclusion (we the nation, which is not your nation) is strongly debated (Gardiner; Mycock). But the SNP promotes its Scottish nationalism in this way.

There is a tension between communicative rationality and instrumentality at the heart of modern nation-state building, identified in the work of Jürgen Habermas. Habermas follows Weber in identifying the role of instrumentality in making nation-states more efficient and effective (Habermas, The Theory of Communicative Action). But this instrumentality, for Habermas, leads to the centralization, bureaucracies and trans-national structures that support global capitalism at the expense of the communicative rationality of the human "lifeworld." In the European Union, Habermas sees a potentially communicative future, so long as its commitment to regionalism and subsidiarity is complemented by proper democratic decision-making and oversight (Habermas, The Lure of Technocracy). In such a supra-national communicative space, it may be possible for local and regional spaces to be given freedom and autonomy within a federation of such spaces - this is the hope, for example, of the SNP. This possible future is, for Habermas, at risk from the growing romantic nationalism of late modernity, where nation-states remain in thrall to the power of 
racial purity, closed borders and ancestral myths of superiority, even as - or because - the world becomes global, liquid and post-modern (Habermas, Post-National).

\section{Methods}

At the heart of my method is a case study developed over three years of passive on-line observation, coupled with content analysis and systematic discourse tracing. The study has focussed on Facebook, metal-archives.com, and other metal news sites. I am a heavy metal fan and an insider in the extreme metal scene, and despite the caution aired about insider research by Andy Bennett (the insider as naïve fan, the insider not seeing the meaning and purpose of the scene in wider society), being a critical insider ${ }^{2}$ enables a researcher to understand the deep myths and symbols of belonging and exclusion that shape music and other sub-cultural leisure spaces. Being a critical insider allows me to have understanding and empathy of my subjects, while maintaining critical distance (Giddens 337). My knowledge of the sub-cultural spaces and its myths and symbols mean I have been an embodied ethnographer since I started to grow my hair long. Although this particular research project and case study of Scottish extreme metal bands, Scottishness and Scottish independence is new, it is related to my wider research programme on heavy metal as a leisure space for identity-making (Spracklen, “To Holmgard...”). This in turn is part of my attempt to explore the limits of agency in identity-making in leisure (Spracklen, Whiteness; Spracklen, Digital). The techniques used in this paper are the same as those used in two papers previously published by me and my colleagues on the exploration of identity-making in extreme metal bands from the north of England (Lucas, Deeks and Spracklen; Spracklen, Lucas and Deeks).

\footnotetext{
${ }^{2}$ I am also a critical insider to British politics, belonging to the English Green party in the north of England and finding myself agreeing with the anti-austerity, pro-social justice politics of the SNP.
} 
This research project followed used discourse tracing in the design, data collection and analysis stages. LeGreco and Tracy show that discourse tracing is related to critical discourse analysis, grounded theory and other qualitative methods, but crucially, discourse tracing allows researchers to develop a fuller picture of the micro, meso and macro level of interpretation and meaning. In this project, meaning is in the process of being constructed in the discourses of music fans, in the discourses of the musicians and journalists, and in the wider political discourses of the Scottish independence movement and Scotland.

\section{Cnoc An Tursa}

Cnoc An Tursa are not big enough to have an entry on Wikipedia. On their official Facebook page they have 6359 fans liking the page (as of 26 April 2016), which compares with the number of likes for the northern English extreme metal bands discussed in Spracklen, Lucas and Deeks, but which is considerably lower than the hundreds of thousands of Facebook likes the biggest European folk metal bands can earn (Spracklen, "To Holmgard...”). The picture at the top of their Facebook page shows the band members in their kilts, in the shadow of a mountain and by a loch, with face-paint inspired by the movie Braveheart (Hesse; McArthur). On metal-archives.com, the band is described as being black/folk metal with lyrical themes including Scottish history and poetry, and their band name is identified as a phrase of Scottish Gaelic, translated as "Hill of the Standing Stone" (Metal Archives, "Cnoc An Tursa"). There is a different, less real/more stylized picture of the band wearing tartan kilts with black shirts, standing in front of a loch on green grass, with mountains in the background. The same picture is found on their official web-site, which gives this information about the band's purpose and history:

Cnoc An Tursa are a Scottish Metal Band forged in Falkirk 2006 by Alan Buchan and Rene Hill, and ancient Borough whose Motto is: "Better Meddle wi' the De'il than 
the Bairns O' Falkirk". Cnoc An Tursa create intense, epic ballads combined with the tales of a much neglected art form; old Scottish poetry. Their sound represents a totally unrivaled (sic) form of heavy Scottish metal with ravenous melodic undertones and ancient rhythmical lyrics, capturing a sound deeply rooted in ancient heritage; giving a fresh perspective on what Scottish metal has to offer. (Cnoc An Tursa, "Biography")

Falkirk is not in the Scottish Highlands and Islands, it is in the heavily-populated, post-industrial Central Belt and faces all the usual problems of small towns denuded of jobs and wealth. The band has been through line-up changes since its formation, and found a key supporter in Chris Naughton, of northern English black metal band Winterfylleth. Despite that band's focus on constructing English identity and Englishness, Cnoc An Tursa found the support crucial in getting them signed to Candlelight Records:

Having played with the likes of Taake and Wodensthrone as well as a full UK tour with label mates Winterfylleth in the winter of 2010 the band gathered a large following and label interest, the band was picked up by Chris Naughton at Lone Vigil Recordings who introduced their debut album The Giants of Auld to Candlelight records for release. (Cnoc An Tursa, "Biography”)

At the time, Candlelight Records was a big independent metal music label, based in the United Kingdom, with a history and specialism in extreme metal, though in 2016 it was bought by a major label. The one album released, 2013's The Giants of Auld, has traditional Scottish pipes and other folk instruments (or keyboard samples of such) added here and there. The album has one review on metal-archives.com, which is worth quoting at length to show how the reviewer connects the band to Celticness and a wider Celtic folk metal exemplified by two Irish bands Cruachan and Primordial: 
There are few bands that could pull off such an honest and authentic portrayal of lush Celtic melodies interweaving between the harsh and forlorn essence of black metal as yours, and some of the immortal legends in this court such as Cruachan and Primordial would be proud of your conviction and faith ... "The Giants of Auld" is far from a complicated album in both concept and execution. The record is merely eight folk-based black metal anthems (plus an intro and an instrumental exit) that are all geared in a similar fashion throughout its entirety ... It's both elegant and mighty: minor keyboards and folk touches graze several heavy and melancholic riffs and melodies mixed with standard extreme metal percussion, but the comprehensive atmosphere is what makes it beyond typical. There's a demanding presence about this piece that's surging through the veins of Cnoc An Tursa's work, and it's an enjoyable performance throughout. (GuntherTheUndying)

In an undated interview on a Dutch extreme metal web-site, one of Cnoc An Tursa's founders Rene Hill talks about the band's lyrical focus on a nationalist version of Scottish history. Their history is the history of the wars and battles that shaped the rise and fall of independent Scotland: the great victories over the English such as Bannockburn in 1314, and the last violent uprising against the English in the eighteenth century, which led to the tragedy of Culloden Moor. The musician goes on to situate the music in the romantic landscape of the Highlands of Scotland, a landscape of shadows, rain, lochs and mountains. As he explains: We wanted something that related purely to Scotland and the content and historical significance of the poems we use does just that. The poetry itself deals with a mix of historical issues such as the track 'Culloden Moor', where Prince Charles Edward Stuart's Highlanders perished in the last, vain battle of the Jacobite Uprising and 'Bannockburn' by Sir Walter Scott which is a graphic account of the Battle of Bannockburn. Other tracks like 'Winter Dirge' and 'Shadowlands' describe the 
desolate Scottish landscapes, scenery and weather. (Hill, "Interview with Cnoc An Tursa")

The journalist then asks Hill about the prospect of Scottish independence, dating the interview to sometime before 2014. The journalist wonders if independence is something that is supported by the majority, or just a minority. The answer is as interesting as the question:

Our first Minister, a Scottish Nationalist, is desperately trying to persuade voters to vote for Scottish Independence in 2014, but I doubt very much that this is going to happen. Many people are apathetic and the majority of those who do vote want to remain part of the United Kingdom. I believe that independence is definitely a wish from the minority and will remain so. (Hill, "Interview with Cnoc An Tursa") Cnoc An Tursa's pessimism about the result turned out to be correct, but it is strange to hear a supporter of Scottish independence saying most of the people in Scotland do not want to split from the United Kingdom. In the second volume of the fanzine Northern Darkness, published early in 2014, Hill is asked again about Scottish independence - is he in favour? In this more intimate space, he responds:

YES, this is extremely important to the whole band and we are voting YES for independence, ultimately what is boils down to is Scotland having the opportunity to make their own changes that can benefit the Scottish people and do what they do best to create a fairer nation, it may be a rocky start but I believe Scotland is strong enough to stand on its own two feet, we have the resources/exports for Scotland to thrive on its own. (Hill, “Cnoc An Tursa” 22)

On their own Facebook page, the band spend most of their time posting information about gigs and merchandise, and plugging their own music on-line. All their own content is uncontroversial and typical of any rock or metal band trying to sell their wares in the post-big label, digital age. But on 17 September 2014, the day before the independence referendum, 
Cnoc An Tursa break cover. Referencing the Battle of Bannockburn of 1314, and providing a link to their own song on the battle ("Bannockburn"), they urge the people of Scotland to vote yes:

Our destiny is almost upon us people of Scotland unite like we did in 1314 and vote yes for the future of our country. (Cnoc An Tursa, "Facebook")

\section{Saor}

Saor is essentially the studio project of one musician - Andy Marshall - who has brought in guest musicians as necessary, for example for live performances but also to play key parts on the recordings such as drums, bodhran, strings, viola and Gaelic voice. Marshall was previously in the black-metal band Falloch, named after the Falls of Falloch to the north of Loch Lomond, close enough to Glasgow to be the subject of day-trips and walks out to the country above the line of the Highland Fault. Marshall started his solo project and released its first album under the name Àrsaidh (ancient in Scottish Gaelic), but for the second album changed to Saor, a reference to the phrase Saor Alba (Free Scotland in Scottish Gaelic) used by modern-day campaigners for Scottish independence (Gardiner). Like Cnoc An Tursa, the band has a small number of Facebook likes (20,687 as of 26 April 2016) comparable with other British folk/black/extreme metal bands. Again, they are not big enough to have a Wikipedia page of their own. The picture on their Facebook page is a visually stunning mountain side and steep-sided glen, photographed in the rain. On metal-archives.com the band is described as "Atmospheric Folk/Black Metal" and their lyrical themes as "Scottish Heritage, Highland Nature/Landscapes, Sorrow" (Metal Archives, “Saor”). The band does not have its own web-site, relying on Bandcamp to sell merchandise and music, and Facebook and other social media for posting news and interaction with fans. 
The first album Roots was released by a label called Fortriu Productions, which to date has only ever released this album and one by another of Marshall's projects. Fortriu is the name of a Pictish kingdom in the early Middle Ages (one of the kingdoms that eventually merged with Alba). We can surmise the label is Marshall's own. The second album Aura followed on the same label, but its release has led to Saor signing a deal with respected underground black metal label Northern Silence Productions. The reception of both albums in the global extreme metal scene has been positive: on metal-archives.com (as of 26 April 2016) Roots has five reviews with an average rating of $86 \%$; and Aura has three with an outstanding average of $91 \%$. Here is an example of one of the reviews of Aura, to give a flavour of the ways in which the fan is constructing a hyper-reality of Scotland and Scottishness in Eco's sense through listening to the music:

It is truly a journey through Scottish legacy and the country's natural beauty. Aura is delivered with a patriotic fervor and yet includes the sensitivity and an inherent splendor that is the result of a man's hard work who is truly loves his job and country. I daresay, if you let your mind wander and absorb the Celtic melodies, the images of the misty highlands appear out of thin air. First of all, it's the Celtic instrumentation that is primarily dominant across the album along with chants and clean vocals (female vocals included). The atmospheric black metal elements running behind the dominant sound add a very powerful vibe to the gigantic melodies. 'Children of the Mist' invokes images of a march of medieval Scottish tribes on their way to battle ... 'The Awakening' pays tribute to poet Robert Burns' depiction of Scotland's beauty in 'My Heart's In The Highlands' which was written in 1789. The song picks off passages from the poem, and an overdose of flute driven melody make it truly magnificent. (dipym666) 
For this reviewer, the genius of Saor's music is its ability to capture something truly authentic and Celtic about Scotland, about its history and its landscapes. The reviewer stresses the combination of furious black metal and Celtic folk instruments and voices combined to make Saor perform as if they are a marching tribe in the Highlands. The reviewer is keen to stress that Marshall is genuinely Scottish and is driven by 'patriotic fervor'. Cnoc An Tursa use the poetry of Walter Scott, favourite of the Victorian elites in nineteenth-century Scotland (and Britain), but then Saor out-patriot them by using the work of Scotland's most Scottish poet: Robert Burns.

As with Cnoc An Tursa, Saor have been interviewed about their thoughts about the landscape and the history that influences them. As Saor are more underground than Cnoc An Tursa, there is less informative content. But in an interview with one on-line fanzine, there are some brief flashes of interest for this paper. In the interview, Marshall is asked to describe his favourite parts of Scotland that are less well-known by tourists. He replies:

I love the epic landscapes, nature, history and cultural heritage of my country, yes. However, most of the big cities and towns in the west of Scotland are dumps and I try and avoid them at all costs. I prefer the rural open spaces of the Highlands and the small communities far away from polluted urban areas. I'm unfortunately situated just outside of Glasgow at the moment but I am planning to move further north next year. (Marshall)

In the answer to this questions, the musician behind Saor becomes a tourist in his own country, sick of the urban space in which he lives, desperate to escape permanently to the invented highlands (the spaces that are imprinted in his own mind as being more Scottish than the cities) which he visits. The next question is a final one that asks him to let the interviewer know the question he has never been asked. Marshall responds to this with the following: 
That's a hard question to answer. I guess I would like to talk more about history, Scottish independence and non-metal music. (Marshall)

If he wants to talk more about Scottish independence, there is nothing explicit about the independence referendum on the Saor Facebook page. Like Cnoc An Tursa, the majority of the posts are related to selling merchandise and music, and letting fans know about gigs. The only reference to the event is an oblique one a few days after the result, when the band posts on 21 September 2014 that "the clan will be invading England" to appear at a festival there (Saor).

However, the band does invoke Scottishness and a romantic idealization of Scottish landscape, through the posting of numerous photographs. Some of these are presumably taken by Marshall, but a few are photos of him in his guise as Saor. These photographs, especially when combined with positive reviews of the band's music, provoke rapturous comments from fans who want to visit Scotland, or who already recognise how beautiful the landscapes of the Highlands and Islands are.

In a post from 3 August 2014, for example, a shot of Andy Marshall shivering on the side of a hill is used to express "pride" in nation, people and place, and to reject modernity. Marshall is wearing a kilt matched strangely with a hoodie with snow on the mountain-tops above him. The picture is next to an on-line review posted by the band to their Facebook page, which talks of the music evoking "a kind or pride that feels true." A fan called Cody Weston feels so connected to Scotland through the music that they know this is where they belong, where they need to visit - even if they do not know if they actually have family ties to the country. In another post on 21 November 2015 is a good example of the atmospheric shots and the reactions they provoke, as well as a stereotypically Scottish response from Saor. The picture is of a track heading through pine trees, with the side of the hills covered in mist. A fan called Rufus Rufus says he is excited about coming to Scotland to drive up into the 
"beautiful landscape," but he is worried about the infamous midges: the flying, biting insects that breed in the cold, damp conditions. Saor reply that the best way to cope with midges is to "drink as much alcohol as possible."

\section{Discussion}

Both bands use their music, their lyrics and their on-line presence to project, construct and perform a particular form of Scottish identity (Wood). This identity is rooted in romantic nationalism, a belief in the injustice of Scotland's merger into what has become the United Kingdom, and a belief in the uniqueness of Scotland's landscape in making it different from its southern neighbor. The bands perform as warriors, embodied in the pictures of Cnoc An Tursa, or the lyrical themes of each band. The music is uplifting and inspiring in a stern, clean way - the music makes its fans want to rise up their own imagined swords and fight the English for this Scottish freedom, for the supposedly authentic Celtic (Gaelic) language and culture, and for hegemonically masculine warrior honor and pride (Hesse; Spracklen, "To Holmgard...”). Saor's invocation of the Highlands and Islands of Scotland invite fans to want to visit them, or to live there, to be at one with Scotland's history, culture and geography (see Hesse; Kader; Matheson; Spracklen, "Dreaming of Drams"; Wood). What we are observing in the production and reception of this particular music is the construction of an imaginary community, a Baudrillardian simulation that is both fantastic and hyper-real, exactly like the northern English ones being constructed in the production and reception of the music of northern English black metal bands (Lucas, Deeks and Spracklen; Spracklen, Lucas and Deeks). That is, these bands and their fans are constructing a sense of community that is symbolic, associated and justified with invented traditions such as the purity of the Scottish landscape, the heroism of the Highlanders in their kilts, and the unquestioned, assumed Celticness of Scotland and Scottish culture. This community is imagined in Anderson's 
definition, even though the community and nation of Scotland has not been legitimized as separate and independent nation: this is imagined community from below, from supposed subalterns in Scotland seeking to find a different form of belonging that is not that of the United Kingdom, or metal fans from other countries who find in the Highland version of Scottish history and place something fulfilling to them.

What both bands perform is a fantastic but simplistic Celticness, and their fans embrace that Celticness, even though Scotland's history and culture is much more complicated than such reductive identities suggest (see Davies; Hesse; McArthur). This Celticness is itself an invented tradition subject to polysemic significations of those who identify with it (Baudrillard; Eco). Why do the bands perform this narrow version of their own cultural and political identity? Why do the fans in Germany or Italy or the Unites States embrace this essentialized, romanticised Celtic identity? The clue is in Andy Marshall from Saor's comments about the towns and cities of the Central Belt, and how he wants to leave them to live in the Highlands. Imagining, constructing and idealizing a Celtic identity linked to the mountains and the warrior clans of the glens allows him to escape the post-industrial, post-modern world. For the bands and their fans, there is a romantic, nostalgic desire to find a world that existed before the uncertainties and pressures of modern life, a world where they suppose people were closer to nature, but also a world of cultural purity and warrior masculinity (Gibson; Hesse). Eco's model of hyper-reality helps account for this performativity of "medieval" Celticness. The musicians know what the Scotland they grew up in is like, the complexity and diversity that cannot be reduced to simple invented traditions. But they are searching for that simplicity and purity, and consciously invent it in the performativity of their bands, knowing it to be simplified and idealized (see the discussion about Velvet Underground in Attias). This performance of Celticness is then 
embraced as authentic by the fans not because they believe it to be true, but because they know it is not true but they want it to be true.

Cnoc An Tursa actively promote their support for the nationalist cause in the Scottish independence referendum, when asked. Saor's Andy Marshall regrets not being asked about his views on Scottish independence. This is probably a failing of the knowledge of journalists in the wider extreme metal scene, a wider apathy towards politics and current affairs in a world heavily mediated by digital technology (Spracklen, Digital). Clearly, both bands promote Scottishness as something distinct from Britishness, and both bands have an interest in creating and maintaining Scotland's cultural and political independence. Both bands have emerged at a time when Scottish nationalism is on the rise, re-claiming Scottishness, Scottish history and Scottish culture. Their nationalism is framed by the civic nationalism of the SNP and the Habermasian communicative rationality that has seemingly created the idea of Scotland as a choice against capitalism and hegemony - the idea of Scotland as an inclusive, democratic "lifeworld," free to choose its own destiny (as Cnoc An Tursa say, mirroring the SNP's political rhetoric). But both bands - on Facebook - also limited comments on or ignored altogether the political campaign for independence taking place throughout 2014. A romantic, conservative nationalism that uses the fake authenticity of Celticness is allowed in this on-line space, because this sells merchandise and connects with fans. But the party politics of the Scottish independence referendum debate is mainly side-lined so that the instrumentality (Habermas, The Theory of Communicative Action) of the modern music industry can operate: both bands have to be careful not to get into arguments with those campaigning to stay in the United Kingdom, and both have to be careful not to let the parochial politics get in the way of maintaining their audiences. Only on the day before the referendum do Cnoc An Tursa reject the instrumentality and embrace the communicative 
rationality of the new nationalism, if only for a day before they go back to the business of making and selling music.

\section{Conclusion}

There is some progressive ideology in modern Scottish nationalism, and in the music, culture and leisure spaces that surround it. In the case study of Cnoc An Tursa and Saor, we can see fans and musicians actively trying to construct their own sense of Scottishness in the light of the wider movement for Scottish independence. The strident calls for Scotland to stand up for itself, to remember its history (or a certain reading of it) and to overturn the English imperialists is a call reflected in folk, pop and rock music aligned with similar struggles for autonomy and independence from hegemonic rulers. Music has always been a form of art that has the potential to operate communicatively to resist the instrumental power of empire, global capitalism, America and the global North.

The performativity of Scotland in the case of these two bands helps make the case for a new and free nation-state. But that performativity is constrained by two things. Firstly, the Celticness constructed is a fake, and although Baudrillard and Eco (to an extent) say all we have in post-modernity is fake, this fakeness reduces the complexity of actual, lived Scottish histories and places. Eco would agree that there is an actual Scottish past, and actual Scottish space, that is being signified by the hyper-reality and the historical discourses, even if such myth-making is controlled by those with hegemonic power, and even if there is no one "true" Scotland to be found.

Secondly, the performativity is constrained by the need to obey and follow the genre rules of folk/black metal, where folk music is used to construct a hegemonically masculine imaginary community where warrior men fight and die for their "nation" and their "race" (Spracklen, "To Holmgard"; Weston). Scottish nationalism more broadly has the same 
challenge - what is the Scotland nationalists want to be constructed? Scotland can be made by the people who live in it, or people who view it from the outside. But inside Scotland, Scottish nationalists need to ensure that music, culture and leisure spaces are used to allow alternative and myriad communities of belonging to be explored. 


\section{Works Cited}

Anderson, Benedict. Imagined Communities. London: Verso, 1983. Print.

Attias, Bernardo Alexander. "Authenticity and Artifice in Rock and Roll: And I Guess That I Just Don't Care.” Rock Music Studies 3:2 (2016): 131-147. Print.

Baigent, Michael, Richard Leigh, and Henry Lincoln. The Holy Blood and the Holy Grail. London: Jonathan Cape, 1982. Print.

Baudrillard, Jean. The Gulf War Did Not Take Place, Sydney: Power Publications, 1995. Print.

Baxter-Moore, Nick. "The Ties That Bind: Springsteen Fans Reflect on the Live Concert Experience.” Rock Music Studies 3:1 (2016): 80-104. Print.

BBC. "Scottish Referendum: Scotland Votes No to Independence". BBC News Scotland. Web. 19 Sep. 2015. <http://www.bbc.co.uk/news/uk-scotland-29270441>

Bennett, Andy. "Researching Youth Culture and Popular Music: A Methodological Critique." British Journal of Sociology 53:3 (2002): 451-466. Print.

Bohlman, Philip. Focus: Music, Nationalism, and the Making of a New Europe. Abingdon: Routledge, 2010. Print. 
Bratus, Alessandro. "In-between Performance and Mediatization: Authentication and (Re)Live(d) Concert Experience." Rock Music Studies 3:1 (2016): 41-61. Print.

Brown, Dan. The Da Vinci Code. London: Transworld, 2003. Print.

Brown, Peter Robert. "Meet the Mekons: Popular Music, Art, and Cultural Critique." Rock Music Studies 2:1 (2015): 22-45. Print.

Cnoc An Tursa. "Biography." Cnoc An Tursa. Web. <http://cnocantursa.com/>

Cnoc An Tursa. "Facebook Page". Facebook. Web. $<$ https://www.facebook.com/cnocantursa/>

Cohen, Antony. The Symbolic Construction of Community. London: Tavistock, 1985. Print.

Davies, Norman. Vanished Kingdoms: The History of Half-Forgotten Europe. London: Penguin, 2011. Print.

dell'Agnese, Elena. "Welcome to Tijuana: Popular Music on the US-Mexico Border." Geopolitics 20:1 (2015): 171-192. Print.

dipym666. "Review of Aura." Metal Archives. Web. 17 Nov. 2014. <http://www.metalarchives.com/reviews/Saor/Aura/407027/dipym666/235174>

Eco, Umberto. Faith In Fakes: Travels In Hyperreality. London: Picador, 1987. Print. 
Eco, Umberto. Foucault's Pendulum. London: Secker and Warburg, 1989. Print.

Fossum, David. "Westernizing Reform and Indigenous Precedent in Traditional Music: Insights from Turkmenistan.” Ethnomusicology 59:2 (2015): 202-226. Print.

Gardiner, Michael. Time and Action in the Scottish Independence Referendum. London: Palgrave, 2015. Print.

Gibson, Marion. "Wicker Men and Straw Dogs: Internal Colonialism in Celtic Novels and Films 1968-1978.” National Identities 15:2 (2013): 139-156. Print.

Giddens, Anthony. The Constitution of Society: Outline of the Theory of Structuration. Berkeley: University of California Press, 1986. Print.

Gramsci, Antonio. Selections from Prison Notebooks. London: Lawrence and Wishart, 1971. Print.

GuntherTheUndying. "Review of The Giants of Auld." Metal Archives. Web. 01 Jul. 2013. $<$ http://www.metalarchives.com/reviews/Cnoc_an_Tursa/The_Giants_of_Auld/366011/GuntherTheUndying/66 976>

Habermas, Jürgen. The Theory of Communicative Action, Volume One: Reason and the Rationalization of Society. Cambridge: Polity, 1984. Print. 
Habermas, Jürgen. The Theory of Communicative Action, Volume Two: The Critique of Functionalist Reason. Cambridge: Polity, 1987. Print.

Habermas, Jürgen. Post-National Constellation. Cambridge: Polity, 2000. Print.

Habermas, Jürgen. The Lure of Technocracy. Cambridge: Polity, 2015. Print.

Hesse, David. Warrior Dreams: Playing Scotsmen in Mainland Europe. Oxford: Oxford UP, 2014. Print.

Hill, Rene. “Cnoc An Tursa.” Northern Darkness March 2014: 22. Print.

Hill, Rene. "Interview with Cnoc An Tursa.” By Vera, Lords of Metal. Web. $<$ http://www.lordsofmetal.nl/en/interviews/view/id/4653>

Hoad, Catherine. "Ons is Saam: Afrikaans Metal and Rebuilding Whiteness in the Rainbow Nation”. International Journal of Community Music 7:2 (2014): 189-204. Print.

Hobsbawm, Eric and Terence Ranger, eds. The Invention of Tradition. Cambridge:

Cambridge UP, 1983. Print.

Kader, Emily. "Rose Connolly Revisited: Re-Imagining the Irish in Southern Appalachia." Journal of American Folklore 127:506 (2014): 425-447. Print. 
LeGreco, Marianne, and Sarah J. Tracy. "Discourse Tracing as Qualitative Practice." Qualitative Inquiry 15:9 (2009): 1516-1543. Print.

Lucas, Caroline, Mark Deeks, and Karl Spracklen. “Grim Up North: Northern England, Northern Europe and Black Metal.” Journal for Cultural Research 15:3 (2011): 279-296. Print.

Marshall, Andy. "Interview with Saor.” Metal Maniac. Web. 05 Dec. 2014. <http://metalmaniac.com/an-interview-with-saor/>

Matheson, Catherine. "Music, Emotion and Authenticity: A Study of Celtic Music Festival Consumers." Journal of Tourism and Cultural Change 6:1 (2008): 57-74. Print.

McArthur, Colin. Brigadoon, Braveheart and the Scots: Distortions of Scotland in Hollywood Cinema. London: IB Taurus, 2003. Print.

Metal Archives. "Cnoc An Tursa.” Metal Archives. Web. <http://www.metalarchives.com/bands/Cnoc_an_Tursa/3540271358>

Metal Archives. "Saor.” Metal Archives. Web. <http://www.metalarchives.com/bands/Saor/3540373234>

Mouritsen, Per, and Tore Vincents Olsen. "Denmark between Liberalism and Nationalism.” Ethnic and Racial Studies 36:4 (2013): 691-710. Print. 
Mycock, Andrew. "SNP, Identity and Citizenship: Re-imagining State and Nation." National Identities 14:1 (2012): 53-69. Print.

Paterson, Bill. "Questioning the Common Sense: Was Scottish Independence Really an Alternative to UK Neoliberalisation?" Capital and Class 39:3 (2015): 493-514. Print.

Saor. "Facebook Page.” Facebook. Web. < https://www.facebook.com/saorofficial/>

Spracklen, Karl. "Dreaming of Drams: Authenticity in Scottish Whisky Tourism as an Expression of Unresolved Habermasian Rationalities.” Leisure Studies 30:1 (2011): 99-116. Print.

Spracklen, Karl. Whiteness and Leisure. Basingstoke: Palgrave Macmillan, 2013. Print.

Spracklen, Karl. "Bottling Scotland, Drinking Scotland: Scotland's Future, the Whisky Industry and Leisure, Tourism and Public Health Policy.” Journal of Policy Research in Tourism, Leisure and Events 6:2 (2014): 135-152. Print.

Spracklen, Karl. Digital Leisure, the Internet and Popular Culture: Communities and Identities in a Digital Age. London: Palgrave Macmillan, 2015. Print.

Spracklen, Karl. "To Holmgard... and Beyond: Folk Metal Fantasies and Hegemonic White Masculinities.” Metal Music Studies, 1:3 (2015):354-377. Print. 
Spracklen, Karl, Caroline Lucas, and Mark Deeks. "The Construction of Heavy Metal Identity through Heritage Narratives: A Case Study of Extreme Metal Bands in the North of England." Popular Music and Society 37:1 (2014): 48-64. Print.

Weston, Donna. "Basque Pagan Metal: View to a Primordial Past." European Journal of Cultural Studies 14:1 (2011): 103-122. Print.

Wood, Nichola. "Playing with Scottishness: Musical Performance, Non-Representational Thinking and the Doings of National Identity.” Cultural Geographies 19:2 (2012): 195-215. Print.

\section{Discography}

Cnoc An Tursa. Giants of Auld. Candlelight, 2013. CD.

Saor. Aura. Fortriu Productions, 2014.CD.

Saor. Roots. Fortriu Productions, 2013. CD (released originally as Àrsaidh). 